\title{
EL DERECHO CONTRACTUAL ANTIDISCRIMINATORIO: DRITTWIRKUNG Y LIBERTAD NEGOCIAL
}

\author{
ANTI-DISCRIMINATION PRIVATE LAW: \\ DRITTWIRKUNG AND FREEDOM OF CONTRACT
}

\author{
INMACULADA Vivas TESÓN \\ Catedrática de Derecho civil \\ Universidad de Sevilla
}

Recibido: 18.12.2020 / Aceptado: 14.01.2021

DOI: https://doi.org/10.20318/cdt.2021.5976

\begin{abstract}
Resumen: El objetivo de este trabajo es abordar el estudio de las situaciones discriminatorias en el seno de la contratación privada. La actitud de uno de los contratantes hacia las características personales o sociales del otro (como la raza, el género, la orientación sexual, la nacionalidad, la religión o la condición de salud) puede influir en el ejercicio de la autonomía privada que preside las relaciones contractuales, bien impidiéndole el acceso a bienes y servicios mediante la negativa a contratar o bien imponiéndole condiciones más gravosas que a otra persona con rasgos distintivos diferentes. Se analiza el Derecho contractual antidiscriminatorio europeo y español, así como los mecanismos de tutela ante un trato discriminatorio.
\end{abstract}

Palabras clave: relaciones contractuales, discriminación, mecanismos legales de protección.

Abstract: The aim of this paper is to tackle the study of discriminatory situations within private contracting. The attitude of one of the contracting parties towards the personal or social characteristics of the other (such as race, gender, sexual orientation, nationality, religion or health condition) may influence the exercise of the private autonomy that presides over contractual relations, either by preventing the other party from accessing goods and services by refusing to contract or by imposing more onerous conditions on the other party than on a person with different characteristics. European and Spanish anti-discrimination contract law is analysed, as well as the mechanisms of protection against discriminatory treatment.

Keywords: contractual relationships, discrimination, legal protective measures.

Sumario: I. Igualdad y no discriminación en la contratación privada. II. La constitucionalización del Derecho Privado. III. La Drittiwirkung der Grundrechte o eficacia horizontal de los derechos fundamentales. IV. El Derecho contractual antidiscrimatorio. 1. El principio de no discriminación como límite de la libertad contractual. 2. Los mecanismos legales de tutela. 3. El alcance de la prohibición de no discriminación contractual.

\footnotetext{
*El presente trabajo es resultado del Grupo de Investigación PAIDI SEJ617 "Nuevas Dinámicas del Derecho Privado Español y Comparado" de la Junta de Andalucía, del Grupo de investigación consolidado "Discapacidad, Enfermedad Crónica y Accesibilidad a los Derechos" (DECADE) de la Universidad de Alcalá y del Proyecto de investigación "Determinantes legales y éticos del COVID-19", de la Universidad de Alcalá.
} 


\section{Igualdad y no discriminación en la contratación privada}

1. La no discriminación en la contratación entre particulares es uno de esos temas de Derecho civil $^{1}$ que podría considerarse hace tiempo ya totalmente superado. Nada más lejos de la realidad. Es ésta una problemática que nos hemos tomado demasiado a la ligera; precisa de una serena reflexión y de una contundente y eficaz respuesta jurídica.

La supresión de fronteras, las facilidades de los desplazamientos transnacionales y los flujos migratorios han contribuido a que la nuestra sea una sociedad variada, multiétnica y multicultural, una sociedad plural de ciudadanos diversos pero con idénticos derechos. A ello ha de sumarse que la globalización, los avances tecnológicos y la consiguiente digitalización del mercado han hecho surgir nuevas dinámicas (y, cómo no, nuevos problemas jurídicos) en el intercambio de bienes y servicios. Todo ello y recientes intervenciones legislativas invitan a reflexionar acerca de la prohibición de discriminar en las relaciones contractuales entre particulares, lo que, precisamente, motiva estas páginas.

2. Por discriminación contractual ${ }^{2}$ podemos entender todo comportamiento de un particular que limite, niegue o haga más gravoso a un sujeto el acceso a bienes y servicios por razón de ciertas circunstancias personales como, entre otras, la etnia, la nacionalidad, la religión, el género, la orientación sexual, la enfermedad o la discapacidad. Tales prejuicios discriminatorios, considerados "factores de riesgo" (unos inherentes a la persona como la raza o el color y otros de elección personal como la religión) y que debieran ser indiferentes al momento de contraer una relación contractual, encasillan a determinadas personas en colectivos desfavorecidos (disadvantaged groups) a nivel social y vulneran frontalmente la dignidad humana.

La actitud de uno de los contratantes hacia las características personales o sociales del otro (como la raza, el género, la orientación sexual, la nacionalidad, la religión o la condición de salud) puede influir en el ejercicio de la autonomía privada que preside las relaciones contractuales, bien impidiéndole el acceso a bienes y servicios mediante la negativa a contratar o bien imponiéndole condiciones más gravosas que a otra persona con rasgos distintivos diferentes. De este modo, las situaciones discriminatorias se dan, principalmente, bien en la fase precontractual mediante el rechazo rotundo a concluir el contrato o bien a la hora de determinar el clausulado del mismo, brindando un peor tratamiento respecto de otro sujeto sin una adecuada justificación.

No son infrecuentes, lamentablemente, los casos de discriminación en la contratación de seguros de salud y vida cuando el tomador es una persona con discapacidad (p. ej., con Síndrome de Down,

\footnotetext{
${ }^{1}$ Advertimos desde ya al lector que no nos adentraremos en la discriminación en las relaciones laborales, abordando únicamente la problemática en la contratación civil, si bien es innegable la influencia del Derecho del Trabajo en la materia objeto de estudio.

${ }^{2}$ Acerca de la materia, en la doctrina española podemos destacar, entre otros, s. NAVAS NAVARRO, "Negativa a contratar y prohibición de discriminar (Derecho comunitario y Derecho español)", $A D C, 2007$, pp. 1619 a 1640.

Entre los autores italianos que se han ocupado de la problemática, vid. D. MAFFEIs, "La discriminazione religiosa nel contratto", Il Diritto Ecclesiastico, 2006, I, pp. 55 y ss., "Libertà contrattuale e divieto di discriminazione", Riv. trim. Dir. proc. civ., 2008, pp. 401 y ss., Offerta al pubblico e divieto di discriminazione, Milano, 2007 e "Il Diritto contrattuale antidiscriminatorio nelle indagini dottrinali recenti", Nuove leggi civ. comm., 2015, pp. 161 y ss.; D. LA RoccA, "Le discriminazioni nei contratti di scambio di beni e servizi", en BARBERÀ (coord.), Il nuovo Diritto antidiscriminatorio. Il quadro comunitario e nazionale, Milano, 2007, pp. 289 y ss., Eguaglianza e libertà contrattuale nel Diritto europeo. Le discriminazioni nei rapporti di consumo, Torino, 2008; A. GENTILI, "Il principio di non discriminazione nei rapporti civili", Riv. crit. Dir. priv., 2009, pp. 207 y ss.; B. CHECCINI, "Eguaglianza, non discriminazione e limiti dell'autonomia privata: spunti per una riflessione", Nuova giur. civ. comm., 2012, pp. 186 y ss.; G. CARAPEZZA FIGLIA, Divieto di discriminazione e autonomia contrattuale, Napoli, 2013 e "Il divieto di discriminazione quale limite all'autonomia contrattuale", Riv. Dir. civ., 2015, pp. 1387 y ss.; E. NAVARRETTA, "Principio di uguaglianza, principio di non discriminazione e contratto", Riv. Dir. civ., 2014, pp. 560 ss.; C. ULESSI, "Diritti dei consumatori e normativa antidiscriminatoria", Riv. Dir. impr., 2015, I, pp. 199 y ss.; S. PRADUROUX, "Il Diritto contrattuale antidiscriminatorio italiano e francese nel quadro delle fonti europee", Nuova giur. civ. comm., vol. 35, núm. 6, 2019, pp. 1377-1386.

En Alemania, vid. E. PICKER, “Anti-discrimination as a Program of Private Law?”, German Law Journal, vol. 4, Núm. 8, 2003, pp. 771-784 y S. LEIBLE y M. SCHLACHTER (eds.), Diskriminierungsschutz durch Privatrecht, Sellier-European Law Publishers, München, 2006.
} 
esto es, por el mero hecho de tener un cromosoma más), con $\mathrm{VIH}^{3}$ o diabetes, sumándose ahora una nueva condición de salud, el Covid-19 (enfermedad por infección por SARS-CoV-2), la cual, muy probablemente, podría transformarse en una circunstancia discriminatoria a la hora de contratar un seguro de personas como el de asistencia sanitaria o vida, lo que no es cuestión baladí dado que, en muchas ocasiones, aquél está vinculado a otro contrato para obtener financiación. Dicha discriminación por parte de la compañía aseguradora puede consistir, como ya hemos apuntado, bien en el rehúse a contratar el seguro o bien en la imposición de condiciones más onerosas o gravosas sin una justificación objetiva, proporcionada y razonable.

A veces, propietarios e inmobiliarias rechazan a un posible inquilino por el mero hecho de tener un nombre o un acento que conduzca a pensar que es extranjero, un hecho discriminatorio por razón de raza u origen. Durante los tratos preliminares por correo electrónico o a través de mensajería instantánea todo va como la seda, pero cuando propietario e interesado en alquilar una vivienda o habitación se encuentran presencialmente bien los rasgos físicos del posible arrendatario evidencian algún factor de riesgo o bien no, pero a la hora de firmar el contrato proporciona sus datos $\mathrm{y}$, por ejemplo, tiene apellidos árabes (y puede que nacionalidad española); entonces, la cosa cambia repentinamente y la xenofobia y el racismo del casero le conducen a no celebrar el contrato.

3. Ahora bien, en la contratación privada, discriminar tal vez no siempre sea ilegal. Según el diccionario de la Real Academia Española, "discriminar" (del latín, discriminare) significa "seleccionar excluyendo". Es lógico que el arrendador, de entre las distintas opciones posibles que se le presenten, elija a quién alquilarle el inmueble en función, por ejemplo, de su solvencia económica. La elección del "buen inquilino" es comprensible y legal, pero no lo es cuando se discrimina a una persona atendiéndose a su raza, ideología, religión, orientación sexual, condición de salud, etc. De hecho, la segunda acepción de la palabra "discriminar" en el mismo diccionario es "dar trato desigual a una persona o colectividad por motivos raciales, religiosos, políticos, de sexo, de edad, de condición física o mental, etc.". Sería, por ejemplo, el caso de no alquilar una vivienda a inmigrantes o negros o bien imponerles condiciones contractuales más gravosas como el pago de la fianza de seis meses por adelantado, cuando la Ley 29/1994, de 24 de noviembre, de Arrendamientos Urbanos, en su art. 36.1, establece, de forma muy clara, que "a la celebración del contrato será obligatoria la exigencia y prestación de fianza en metálico en cantidad equivalente a una mensualidad de renta en el arrendamiento de viviendas y de dos en el arrendamiento para uso distinto del de vivienda". Ello es, a todas luces, una discriminación odiosa intolerable por su carácter estigmatizador que crea desigualdades sistemáticas derivadas de la categorización social.

4. No son extraños los supuestos de discriminación múltiple en los que el sujeto es estigmatizado por dos o más rasgos odiosos a la vez, por ejemplo, negro y homosexual, mujer y discapacidad.

5. Con ocasión de la crisis mundial provocada por la pandemia del coronavirus que tristemente nos ha tocado vivir, estamos detectando una modalidad particular de conductas discriminatorias, la denominada "discriminación por asociación" (también llamada por vinculación o refleja) ${ }^{4}$ a profesionales

\footnotetext{
${ }^{3}$ Dado que con frecuencia suelen utilizarse como términos sinónimos, queremos subrayar la diferencia entre uno y otro: el Virus de la Inmunodeficiencia Humana (VIH) es un retrovirus caracterizado por actuar sobre el sistema inmunitario de los humanos (en concreto, sobre las células CD4 o células T) y no tiene cura pero sí tratamiento, en tanto que el Síndrome de Inmunodeficiencia Adquirida (SIDA) es la fase más grave de la infección por el VIH, que se caracteriza porque el organismo ya no es capaz de combatir patógenos, por lo que aparecen enfermedades oportunistas que pueden afectar gravemente la salud. Por tanto, siguiendo el tratamiento adecuado, las personas seropositivas pueden mantenerse sanas y no alcanzar nunca la fase de SIDA. Hoy día, según un estudio estadounidense presentado en la XXVII Conference on Retroviruses and Opportunistic Infections (CROI 2020) celebrada en marzo de 2020, las personas con VIH con tratamiento antirretroviral tienen la misma esperanza de vida que las personas no portadoras del virus, pero presentan, en su proceso de envejecimiento, comorbilidades que aparecen antes y que hacen que su calidad de vida fuera inferior a la observada en la población general.

${ }^{4}$ Aplicando la doctrina jurisprudencial sentada por el Tribunal de Justicia de la Unión Europea desde la famosa Sentencia 17 julio 2008 (TJCE 2008, 176, asunto C-303/06, Coleman), nuestro Tribunal Constitucional, en su reciente Sentencia 71/2020, 29 junio (RTC 2020\71), estima un recurso de amparo en el que se alega vulneración del art. 14 de la Constitución española por acto discriminatorio por razón de sexo en relación a un supuesto de discriminación por asociación de una traba-
} 
del ámbito sanitario que trabajan a diario con pacientes con Covid-19, a quienes se "invita" a resolver anticipadamente el contrato de arrendamiento. Al margen de la concreta modalidad arrendaticia pactada y, por consiguiente, de la norma aplicable al mismo (el Código civil o la Ley de Arrendamientos Urbanos), un motivo de salud no puede jamás obligar al arrendatario a abandonar forzosamente la vivienda o la habitación en alquiler. Únicamente el arrendador, y por motivos debidamente acreditados que contravengan la norma o el acuerdo arrendaticio, como el impago de la renta o el incumplimiento de las condiciones voluntariamente estipuladas, como introducir un animal de compañía en el inmueble habiéndose pactado su prohibición, puede instar la resolución del contrato.

6. Y por si todo ello fuera poco (que no lo es), clama al cielo que sea el propio legislador quien, guiado por absurdos prejuicios, discrimine a los particulares a la hora de contratar servicios, lo que es de todo punto inadmisible.

Como muestra un botón: el legislador andaluz, en el art. 19 del Decreto 71/2017, de 13 de junio, por el que se regulan las condiciones higiénico-sanitarias y técnicas de las actividades relativas a la aplicación de técnicas de tatuaje, micropigmentación y perforación cutánea piercing, se ocupa de las posibles complicaciones y contraindicaciones que podrían producir en determinados usuarios de tales técnicas (p. ej. mujeres embarazadas y madres en situación de lactancia, personas con diabetes, con hemofilia, con cardiopatías, portadoras de VIH o de hepatitis B o C, inmunodeprimidas o portadoras de prótesis valvulares, ortopédicas y vasculares), a quienes la persona aplicadora debe informar tanto de forma oral como escrita.

Pues bien, en su apartado $2^{\circ}$, el citado precepto reza así: "2. La persona aplicadora se podrá negar a llevar a cabo la aplicación de las técnicas de tatuaje, micropigmentación o perforación cutánea piercing, a la vista de las contraindicaciones que pudiera presentar la aplicación de dichas técnicas respecto a una determinada persona que quisiera ser usuaria de las mismas". Dicho de otro modo, la persona aplicadora encuentra amparo legal para denegar un servicio, por ejemplo, a una persona con VIH, en lugar de haberse previsto por parte del legislador algo tan sencillo como la obligación de utilizar para la realización de tales técnicas material esterilizado desechable. Nos cuesta mucho entender cómo esta norma discriminatoria, tras la cual existe un profundo desconocimiento de algunas enfermedades además de una nula sensibilidad, forma parte, a día de hoy, de nuestro ordenamiento jurídico. Sobra decir que la persona usuaria a la que se le deniega la prestación consistente en la relación de un tatuaje o un piercing, pese al daño del estigma o discriminación que reporta ella y su entorno, nada podrá hacer ante una discriminación arbitraria pero, sorprendentemente, legal. A nuestro juicio esta norma (y no es la única) debería ser expulsada de nuestro Ordenamiento jurídico.

7. En la práctica, son escasas las ocasiones en que este tipo de conductas discriminatorias en el ámbito de las relaciones contractuales que permiten el acceso y suministro de bienes y servicios dan lugar a pronunciamientos judiciales, sobre todo, por su dificultad probatoria. Sin embargo, ello no quiere decir que no existan.

8. Cierto es que la penetración de la prohibición de discriminar en el Derecho contractual como límite de la autonomía privada podría suponer un vaciamiento sustancial de la libertad de pactar con quien se desee reconocida en el art. 1255 del Código civil (en adelante, C.c.), principio basilar del tráfico jurídico-privado, tanto del nacional como del comunitario, y, sin duda, un valor a proteger. Se trata de un área del Derecho civil en el que suele hablarse de libertad, razón por la cual las injerencias e imposiciones no son bienvenidas. La igualdad en la contratación privada no existe; es más, muchos son los supuestos contractuales en los que existe una clara desigualdad entre los contratantes.

jadora con vínculo estatutario fijo como enfermera de un hospital dependiente del Servicio Vasco de Salud, quien tras solicitar el disfrute de un permiso de dos días de duración por la hospitalización de su hermana por razón de parto, le fue denegada la licencia solicitada por entenderse que no tenía derecho a la misma al tratarse de una hospitalización por razón de parto. Según el Tribunal Constitucional, "es pertinente tener en consideración que tanto el Tribunal de Justicia de la Unión Europea como el Tribunal Europeo de Derechos Humanos, han admitido que se incurre en discriminación refleja cuando una persona es tratada de forma menos favorable por causa de su vinculación o asociación con otra que posee uno de los rasgos o características protegidas (o las causas de discriminación prohibidas), pese a no poseer dicha característica en quien alega el trato discriminatorio". 
Es evidente que una sociedad democrática avanzada (según el art. 1.1 de la CE, "España se constituye en un Estado social y democrático de Derecho, que propugna como valores superiores de su ordenamiento jurídico la libertad, la justicia, la igualdad y el pluralismo político"), por tanto, plena e inclusiva, no debe consentir la discriminación y consiguiente estigmatización de las personas que la integran: todos somos ciudadanos plenos e iguales en derechos y así debemos ser tratados, sin excepción, en todos los ámbitos vitales.

Por ello, hoy día, en desarrollo del art. 14 de nuestra Constitución (en adelante CE) ${ }^{5}$ y al derecho a no ser discriminado que consagra ("los españoles son iguales ante la ley, sin que pueda prevalecer discriminación alguna por razón de nacimiento, raza, sexo, religión, opinión o cualquier otra condición o circunstancia personal o social"), existe un Derecho antidiscriminatorio, esto es, mecanismos de protección contra la discriminación, si bien, como bien puede intuir el lector, tales remedios no son suficientemente disuasorios y mucho menos en el Derecho privado.

\section{La constitucionalización del Derecho privado}

9. El art. 1 de la Declaración de los derechos del hombre y del ciudadano de 1789 dispone que "los hombres nacen y permanecen libres e iguales en derechos".

Es innegable que los valores de la libertad e igualdad ${ }^{6}$ hunden sus raíces en la dignidad humana, fundamento de los derechos humanos y del sistema democrático. La íntima conexión entre libertad, igualdad y dignidad humana, un pack esencial e inescindible, se detecta, con suma claridad, en el art. 1 de la Declaración universal de derechos humanos de 1948, el cual dispone que "todos los seres humanos nacen libres e iguales en dignidad y derechos y, dotados como están de razón y conciencia, deben comportarse fraternalmente los unos con los otros".

La persona, en su dimensión individual, es libre y, en su dimensión relacional, es igual a los demás?

El binomio libertad-igualdad se remonta, como es sabido, a la Revolución francesa, esto es, a los cimientos de la Edad moderna, entroncando directamente con la idea de justicia. Ello nos permite evocar los tres clásicos principios del Derecho (tre iura pracepta) formulados por Ulpiano: honeste vivere (vivir honestamente), alterum non laedere (no hacer daño a otro), suum cuique tribuere (dar a cada uno lo suyo). Son estas tres máximas las que deben regir en todo momento las relaciones jurídicas y, por cuanto aquí nos interesa, las entabladas entre particulares.

10. Acerca del derecho a la igualdad y no discriminación consagrado en el art. 14 de la CE, el Tribunal Constitucional, en su Sentencia 200/2001, 4 octubre $^{8}$, nos recuerda su reiterada doctrina, la cual se remonta a los años $80^{9}$, del siguiente modo: "el art. $14 \mathrm{CE}$ contiene en su primer inciso una cláusula general de igualdad de todos los españoles ante la Ley, habiendo sido configurado este principio general de igualdad, por una conocida doctrina constitucional, como un derecho subjetivo de los ciudadanos a ob-

\footnotetext{
${ }^{5}$ Repárese en que el art. $14 \mathrm{CE}$, en línea con algunos Instrumentos internacionales como la Declaración Universal de derechos humanos, el Pacto internacional de derechos civiles y políticos, el Pacto internacional de derechos económicos sociales y culturales o el Convenio europeo de derechos humanos, contiene una cláusula abierta y flexible al disponer que no puede prevalecer ninguna discriminación "por cualquier otra condición o circunstancia personal o social", lo que permite una mayor adaptación a la aparición de nuevas causas discriminatorias a tenor de los cambios sociales y económicos.

De este modo, entre los factores de riesgo mencionados en el art. 14 CE no se encuentra la enfermedad y, sin embargo, la STC 62/2008, 26 mayo (RTC 2008\62), en relación a un despido por razón de salud, no duda a la hora de considerarla una causa discriminatoria incluida en dicho precepto: "no cabe duda de que el estado de salud del trabajador o, más propiamente, su enfermedad, pueden, en determinadas circunstancias, constituir un factor de discriminación análogo a los expresamente contemplados en el art. $14 \mathrm{CE}$, encuadrable en la cláusula genérica de las otras circunstancias o condiciones personales o sociales contemplada en el mismo" (FJ $6^{\circ}$ ).

${ }^{6}$ Vid. N. BOBBio, Eguaglianza e libertà, Torino, 1995.

${ }^{7}$ Según afirma la STC 200/2001, 4 octubre (RTC 2001, 200), "el juicio de igualdad, por lo demás, es de carácter relacional" $\left(\mathrm{FJ} 4^{\circ}\right)$.

${ }^{8}$ RTC 2001, 200

${ }_{9}^{9}$ SSTC 22/1981, 2 julio (RTC 1981, 22), 34/1981, 10 noviembre (RTC 1981, 34) y 19/1982, 5 mayo (RTC 1982, 19).
} 
tener un trato igual, que obliga y limita a los poderes públicos a respetarlo y que exige que los supuestos de hecho iguales sean tratados idénticamente en sus consecuencias jurídicas y que, para introducir diferencias entre ellos, tenga que existir una suficiente justificación de tal diferencia, que aparezca al mismo tiempo como fundada y razonable, de acuerdo con criterios y juicios de valor generalmente aceptados, y cuyas consecuencias no resulten, en todo caso, desproporcionadas. Como tiene declarado este Tribunal desde la STC 22/1981, 2 julio, recogiendo al respecto la doctrina del Tribunal Europeo de Derecho Humanos en relación con el art. 14 CEDH ( $R C L$ 1999, 1190, 1572), el principio de igualdad no implica en todos los casos un tratamiento legal igual con abstracción de cualquier elemento diferenciador de relevancia jurídica, de manera que no toda desigualdad de trato normativo respecto a la regulación de una determinada materia supone una infracción del mandato contenido en el art. $14 \mathrm{CE}$, sino tan sólo las que introduzcan una diferencia entre situaciones que puedan considerarse iguales, sin que se ofrezca y posea una justificación objetiva y razonable para ello, pues, como regla general, el principio de igualdad exige que a iguales supuestos de hecho se apliquen iguales consecuencias jurídicas $\mathrm{y}$, en consecuencia, veda la utilización de elementos de diferenciación que quepa calificar de arbitrarios o carentes de una justificación razonable. Lo que prohíbe el principio de igualdad son, en suma, las desigualdades que resulten artificiosas o injustificadas por no venir fundadas en criterios objetivos y razonables, según criterios o juicios de valor generalmente aceptados. También es necesario, para que sea constitucionalmente lícita la diferencia de trato, que las consecuencias jurídicas que se deriven de tal distinción sean proporcionadas a la finalidad perseguida, de suerte que se eviten resultados excesivamente gravosos o desmedidos.

En resumen, el principio de igualdad, no sólo exige que la diferencia de trato resulte objetivamente justificada, sino también que supere un juicio de proporcionalidad en sede constitucional sobre la relación existente entre la medida adoptada, el resultado producido y la finalidad pretendida (SSTC 22/1981, 2 julio, F. 3; 49/1982, 14 julio [RTC 1982, 49], F. 2; 2/1983, 24 enero [RTC 1983, 2], F. 4; 23/1984, 20 febrero [RTC 1984, 23], F. 6; 209/1987, 22 diciembre [RTC 1987, 209], F. 3; 209/1988, 10 noviembre [RTC 1988, 209], F. 6; 20/1991, 31 enero [RTC 1991, 20], F. 2; 110/1993, 25 marzo [RTC 1993, 110], F. 6; 176/1993, 27 mayo [RTC 1993, 176], F. 2; 340/1993, 16 noviembre [RTC 1993, 340], F. 4; 117/1998, 2 junio [RTC 1998, 117], F. 8, por todas).

Esto así, el principio genérico de igualdad no postula ni como fin ni como medio la paridad pero sí exige la razonabilidad de la diferencia normativa de trato".

En su posterior Sentencia 27/2004, 4 marzo $^{10}$, el Tribunal Constitucional afirma que "la prohibición de discriminación contenida en el art. $14 \mathrm{CE}$ representa un explícito rechazo de determinadas diferenciaciones históricamente muy arraigadas y que han situado a sectores de la población, tanto por la acción de los poderes públicos como por la práctica social, en posiciones, no sólo desventajosas, sino abiertamente contrarias a la dignidad de la persona que reconoce el art. $10 \mathrm{CE}$ " (FJ $2^{\circ}$ ). En esta línea, en su Sentencia 62/2008, 26 mayo ${ }^{11}$, precisa que "lo que caracteriza a la prohibición de discriminación, frente al principio genérico de igualdad, es la naturaleza particularmente odiosa del criterio de diferenciación utilizado, que convierte en elemento de segregación, cuando no de persecución, un rasgo o una condición personal innata o una opción elemental que expresa el ejercicio de las libertades más básicas, resultando así un comportamiento radicalmente contrario a la dignidad de la persona y a los derechos inviolables que le son inherentes (art. $10 \mathrm{CE}$ )".

Así las cosas, en cuanto al alcance de la igualdad ante la ley, no toda desigualdad es discriminatoria, puesto que es posible una diferencia de trato siempre que se sustente en una justificación objetiva, proporcionada y razonable.

11. La Carta de los derechos fundamentales de la Unión Europea dedica su Título I y los cinco preceptos que lo integran a la dignidad. "La dignidad humana es inviolable. Será respetada y protegida", afirma en su art. 1, en tanto que en sus arts. 20 a $26^{12}$ reconoce el derecho a la igualdad.

\footnotetext{
${ }^{10}$ RTC 2004\27.

${ }^{11}$ RTC 2008\62.

${ }^{12}$ Art. 20: Igualdad ante la ley

"Todas las personas son iguales ante la ley".
} 
Con anterioridad a su explícita plasmación en el ordenamiento jurídico comunitario de la que más adelante nos ocuparemos, el principio de igualdad se infería a partir de una interpretación sistemática por parte del Tribunal europeo de Justicia de la prohibición de discriminación contenida en los diferentes Tratados. Y así, según reiterada jurisprudencia del citado Tribunal ${ }^{13}$, "el principio general de igualdad de trato, como principio general del Derecho comunitario, exige que no se traten de manera diferente situaciones comparables y que no se traten de manera idéntica situaciones diferentes, a no ser que dicho trato esté objetivamente justificado".

12. Claro lo anterior y sin poder adentrarnos ahora en las profundidades del fenómeno de la "constitucionalización" del Derecho privado, no sólo por motivos de síntesis sino, sobre todo, por las magistrales reflexiones doctrinales vertidas sobre la materia ${ }^{14}$, nos limitamos a afirmar que los mandatos y principios constitucionales impregnan intensamente todo el Derecho civil que, a la vez y paradójicamente, sufre una "desconstitucionalización" al perder el Código el privilegiado valor constitucional que le fue conferido en el siglo XIX. La norma civil ha de ser necesariamente interpretada de acuerdo con los postulados, principios y orientaciones emanados de la Norma Suprema. Ello obliga a una relectura de la legislación civil a la luz de la Constitución, que actúa externamente como límite o barrera de la norma ordinaria. Es preciso, además, lograr una verdadera actuación de los principios constitucionales a través de las normas civiles, de las que aquéllos vendrían a ser como la guía interna; la Constitución y sus principios deben penetrar en el interior mismo del Derecho civil vitalizándolo íntegramente, constituyéndose en la fuerza inspiradora de la aplicación e interpretación de sus normas.

Desde esta perspectiva axiológica nos ocupamos del Derecho contractual antidiscriminatorio, en el cual ha de lograrse la perfecta reconciliación de los principios de libertad e igualdad. No es tarea fácil pero, en el Derecho privado de hoy, como consecuencia de la aplicación de las normas imperativas o de Derecho cogente tanto europeas como nacionales, las cuales determinan la interpretación e integra-

\footnotetext{
Art. 21: No discriminación

"1. Se prohíbe toda discriminación, y en particular la ejercida por razón de sexo, raza, color, orígenes étnicos o sociales, características genéticas, lengua, religión o convicciones, opiniones políticas o de cualquier otro tipo, pertenencia a una minoría nacional, patrimonio, nacimiento, discapacidad, edad u orientación sexual.

2. Se prohíbe toda discriminación por razón de nacionalidad en el ámbito de aplicación del Tratado constitutivo de la Comunidad Europea y del Tratado de la Unión Europea y sin perjuicio de las disposiciones particulares de dichos Tratados".

Art. 22: Diversidad cultural, religiosa y lingüística

"La Unión respeta la diversidad cultural, religiosa y lingüística".

Art. 23: Igualdad entre hombres y mujeres

"La igualdad entre hombres y mujeres será garantizada en todos los ámbitos, inclusive en materia de empleo, trabajo y retribución. El principio de igualdad no impide el mantenimiento o la adopción de medidas que ofrezcan ventajas concretas en
} favor del sexo menos representado".

Art. 24: Derechos del menor

"1. Los menores tienen derecho a la protección y a los cuidados necesarios para su bienestar. Podrán expresar su opinión libremente. Ésta será tenida en cuenta en relación con los asuntos que les afecten, en función de su edad y de su madurez.

2. En todos los actos relativos a los menores llevados a cabo por autoridades públicas o instituciones privadas, el interés superior del menor constituirá una consideración primordial.

3. Todo menor tiene derecho a mantener de forma periódica relaciones personales y contactos directos con su padre y con su madre, salvo si son contrarios a sus intereses".

Art. 25: Derechos de las personas mayores

"La Unión reconoce y respeta el derecho de las personas mayores a llevar una vida digna e independiente y a participar en la vida social y cultural".

Art. 26: Integración de las personas discapacitadas

"La Unión reconoce y respeta el derecho de las personas discapacitadas a beneficiarse de medidas que garanticen su autonomía, su integración social y profesional y su participación en la vida de la comunidad".

${ }^{13}$ Por todas, STJCE (Gran Sala) 16 diciembre de 2008 (TJCE 2008\309), caso Société Arcelor Atlantique et Lorraine y otros contra Premier ministre, Ministre de l'Écologie et du Développement durable y Ministre de l'Économie, des Finances et de l'Industrie.

${ }^{14}$ Entre ellas, las de los maestros de nuestra Universidad hispalense, B. CLAVERO SALVADOR, "Codificación y Constitución: paradigmas de un binomio", Quaderni Fiorentini, 1989, pp. 79-145, así como A. LóPEZ y LóPEZ, "Constitución, Código y leyes especiales. Reflexiones sobre la llamada descodificación”, en Centenario del Código Civil, T. II, Madrid, 1990, pp. 1163-1176 y El Derecho civil entre tradición histórica y constitución política, Navarra, 2016. 
ción de los pactos entre particulares (arts. 1255 y 1258 del C.c.), de no ser posible encontrar el deseado equilibrio, éste se rompe en contra de la autonomía contractual, mermándola.

\section{La Drittwirkung der Grundrechte o eficacia horizontal de los derechos fundamentales}

13. Como acabamos de ver, nuestra Carta Magna recoge un conjunto de valores con relevancia exegética en el ámbito civil. Conforme a ello, que toda norma deba aplicarse siempre de manera que se maximalice, en lo posible, la eficacia de los derechos fundamentales es un recurso hermenéutico a disposición de los Tribunales que se introduce en el art. 3.1 del C.c., un nuevo canon interpretativo que, a diferencia de los enumerados en dicho precepto, es un criterio superior que impone una jerarquía argumental: la interpretación secundum Constitutionem.

14. El art. 53.1 de la CE establece la vinculación de los derechos fundamentales en ella reconocidos a todos los poderes públicos. Nada dice, sin embargo, de la incidencia de los derechos fundamentales en el Derecho privado y, más concretamente, si el titular de los mismos está protegido únicamente frente a la injerencias de los poderes públicos (relación de subordinación) o también frente a las vulneraciones por parte de otros individuos igualmente titulares de derechos fundamentales (relación de coordinación). Dicho de otro modo, se plantea la eficacia horizontal de los derechos fundamentales en las relaciones inter privatos, la archiconocida, con terminología alemana, Drittwirkung der Grundrechte ${ }^{15}$, y su consiguiente merma del poder de autorregulación de intereses particulares en que consiste la autonomía privada.

\footnotetext{
${ }^{15}$ La tesis de la Drittwirkung fue elaborada por el iuslaboralista H. C. NIPPERDEY, Grundrechte und Privatrecht, Munich, 1961 y seguida por el Tribunal Federal de Trabajo, que él mismo presidió de 1954 a 1963.

En la doctrina alemana, vid. G. DÜRIG, "Grundrechte und Zivilrechtsprechung”, Festschrift für Nawiasky, 1956, pp. 157 y ss.; R. GEIGER, Die Grundrechte in der Privatrechtsordnung, Stuttgart, 1960; J. SCHWABE, Die sogenannte Drittwirkung der Grundrechte: Zur Einwirkung der Grundrechte auf den Privatrechtsverkehr, München, 1971; C-w. CANARIs, "Grundrechte und Privatrecht", Archiv für die civilistische Praxis (AcP) 184 (1984), pp. 201 y ss.; L. RAISER, Il compito del Diritto Privato, trad. it. de raziadei, Milano, 1990; D. MEDicus, "Der Grundsatz der Verhältnismäßigkeit im Privatrecht”, AcP 192 (1992), pp. 35 y ss.; R. ALEXY, Teoría de los derechos fundamentales, trad. de Garzón Valdés, Madrid, Centro de Estudios Constitucionales, 1993; J. AGER, “Grundrechte im Privatrecht”, JuristenZeitung, núm. 49, 1994, pp. 373 y ss.; K. HESSE, Derecho Constitucional y Derecho Privado, trad. e introduc. de Gutiérrez Gutiérrez, Madrid, 1995; I. VON MÜNCH, "Drittwirkung de derechos fundamentales en Alemania”, en SALVADOR CODERCH (cood.), Asociaciones, derechos fundamentales y autonomía privada, Madrid, 1997, pp. 30 y ss.; A. GUCKelberger, "Die Drittwirkung der Grundrechte", Juristische Schulung, 2003, pp. 1151 y ss.; M. BOROwSKI, "La Drittwirkung ante el trasfondo de la transformación de los derechos morales en derechos fundamentales", Revista Derecho del Estado, núm. 45, 2020 (disponible en https://ssrn.com/abstract=3519474).

Entre los autores italianos que se han ocupado de la materia citamos, entre otros, P. RESCIGNO, "Il principio di eguaglianza nel Diritto privato", Riv. trim. Dir. proc. civ., 1959, pp. 1515 y ss. y "Sul cosiddetto principio d'uguaglianza nel Diritto privato", Foro it., 1959, cc. 664 y ss.; G. CARAPEZZA FIGLIA, Divieto di discriminazione e autonomia contrattuale, Napoli, 2012 e "Il divieto di discriminazion quale limite all'autonomia contrattuale”, Riv. Dir. civ., 2016, pp. 1387 y ss.; E. NAVARRETTA, Costituzione, Europa e Diritto privato. Effettività e «drittwirkung» ripensando la complessità giuridica, Torino, 2018; A. IANNi, "L'incidenza della Costituzione sui rapporti privati. Sul divieto di accesso agli stadi il Bundesverfassungsgericht torna ad arbitrare la partita della Drittwirkung", DPCE Online, v. 36, núm. 3, 2018 (disponible en http://193.205.23.57/index.php/dpceonline/article/view/565); A. M. BENEDETTI, "L'autonomia contrattuale come valore da proteggere. Costituzione, solidarietà, libertá (Relazione al Seminario "Drittwirkung: principi costituzionali e rapporti tra privati”, Pavia, 16 maggio 2019)”, Nuova giur. civ. comm., 2019, fasc. 4 pp. 827-831.

En la doctrina española cabe destacar, T. QUADRA SALCEDO, El recurso de amparo y los derechos fundamentales, Madrid, 1981; J. García torres/A. JimÉnez Blanco, Derechos fundamentales y relaciones entre particulares: la Drittwirkung en la jurisprudencia del Tribunal Constitucional, Madrid, 1986; P. CRUZ VILLALÓn, "Derechos fundamentales y Derecho Privado", Academia Sevillana del Notariado, 1988, pp. 97 y ss.; J. F. LóPEZ-AgulLar, Derechos fundamentales y libertad negocial, Madrid, 1990; J. Alfaro ÁGUILA-Real, "Autonomía privada y derechos fundamentales", $A D C, 1993$, pp. 57-122; P. DE VEGA: "Dificultades y problemas para la construcción de un constitucionalismo de la igualdad (el caso de la eficacia horizontal de los derechos fundamentales)", Anuario de Derecho Constitucional y Parlamentario, 1994, pp. 41-56 y "La eficacia frente a particulares de los derechos fundamentales. La problemática de la Drittwirkung der Grundrechte", en AGUIAR DE LuQue (coord.), Constitución, Estado de las Autonomías y Justicia Constitucional, Libro Homenaje al Profesor Gumersindo Trujillo, Valencia, 2005, pp. 801822; A. LÓPEZ Y LÓPEZ, "Estado social y sujeto privado: una reflexión finisecular", Quaderni Fiorentini, 1996, pp. 434 y ss. y El Derecho civil entre tradición histórica y Constitución política, Cizur menor (Navarra), 2016, pp. 69-92; J. Ma . BILBAO UBILLOS, La eficacia de los derechos fundamentales frente a particulares, Madrid, 1997, "Prohibición de discriminación y relaciones entre particulares", Teoría y realidad constitucional, núm. 18, 2006, pp. 147-198 y "La consolidación dogmática y jurisprudencial
} 
Con demasiada frecuencia se esgrime el argumento de la naturaleza privada del sujeto (el lector seguramente estará pensando en el típico cartel en la entrada de algunos establecimientos de ocio abiertos al público en el que puede leerse "queda reservado el derecho de admisión" del que es titular el empresario frente al derecho de acceso del consumidor o usuario) para justificar, con una sedicente legitimidad, situaciones discriminatorias por razón de raza, género, orientación sexual, edad, enfermedad o discapacidad, las cuales conculcan el art. 14 de la CE, que proclama la igualdad de todas las personas y la consiguiente prohibición de discriminación. Lo privado se erige, estratégicamente, en muro o barrera infranqueable frente a cualquier reivindicación paritaria; un refugio para vulnerar derechos fundamentales y, en última instancia, la dignidad de la persona del art. 10 de la CE.

15. Pues bien, los derechos fundamentales, ¿inciden en las relaciones entre particulares?; el respeto a dichos derechos constitucionales, ¿funciona como un límite a la autonomía privada reconocida en el art. 1255 del C.c. y, por tanto, como una restricción de libre actuación de los particulares? ${ }^{16}$.

Como bien se sospechará, dar una respuesta a tales interrogantes en relación al ámbito del Derecho de los particulares (diverso sería en la esfera de lo público) es tarea ardua ${ }^{17}$ : frente a una posición contraria a la virtualidad de los derechos fundamentales en el tráfico jurídico privado, existe otra favorable que se inclina por la horizontalidad directa sin mediar ninguna norma interpuesta, en tanto que otros autores consideran que los derechos fundamentales informan el concreto contenido de las cláusulas y principios generales del Derecho privado como la buena fe, la moral, las buenas costumbres y el orden público (arts. 7.1, 1255 y 1258 del C.c.), conceptos jurídicos abiertos e indeterminados que permiten adecuarse a los continuos cambios sociales.

En nuestra opinión, la superioridad normativa de la Constitución y su potente efecto de irradiación en todo el Ordenamiento jurídico, así como los valores superiores de libertad, justicia e igualdad (formal y material) del Estado social y democrático de Derecho hacen inevitable admitir una cierta operatividad $\mathrm{u}$ horizontalidad de los derechos fundamentales en las relaciones inter privatos, $\mathrm{y}$, por cuanto ahora nos ocupa, en el ejercicio de la autonomía de los particulares a través del contrato, que no es, desde luego, el mismo a la manifestada en el testamento.

Cierto es que el art. 53 CE sólo menciona a los poderes públicos y no a los ciudadanos, si bien son ambos los destinatarios indiscutibles de su art. 9.1 ${ }^{18}$.

de la Drittwirkung: una visión de conjunto", Anuario de la Facultad de Derecho de la Universidad Autónoma de Madrid, núm. 21, 2017, pp. 43-74; R. NARANJO DE LA CRUZ, Los límites de los derechos fundamentales en las relaciones entre particulares: la buena fe, Madrid, 2000; I. VIVAS TESÓN, "La horizontalidad de los derechos fundamentales", en Bienes de la personalidad, Murcia, 2008, pp. 205-213; E. VIEIRA JiMÉNEZ DE ONTIVEROS, "La eficacia horizontal de los derechos fundamentales: arbitraje y derecho a la tutela judicial efectiva", $A D C$, tomo LXXII, 2019, fasc. II, pp. 419-446.

${ }^{16}$ A. LÓPEZ y LÓPEZ, Fundamentos de Derecho civil, Valencia, 2012, p. 315, plantea las siguientes hipótesis: "la de la posible aplicación del principio de igualdad (que, por cierto, es la que, posiblemente, plantee los problemas más agudos en su pretendida extensión a las relaciones de Derecho Privado), tal y como viene formulado por el artículo 14 de la Constitución; a pesar de dicho principio, ¿pueden los estatutos de una asociación deportiva (privada, por definición: artículo $35,2^{\circ}$ del Código civil) establecer que no podrán formar parte de ella los individuos pertenecientes a una determinada etnia?; una persona que se dedique al suministro de bienes y servicios, ¿carece de las posibilidades de establecer con sus clientes el precio y las condiciones de los mismos, una vez que los haya fijado con el primero, porque todos los siguientes tienen el derecho (constitucional) a ser tratados de manera igual?; ¿puede un profesional negarse a prestar sus servicios, o todos tiene derecho a ellos, por aplicación del principio de igualdad?. Y los supuestos, desde luego, no se ciñen en exclusiva al principio de igualdad: ¿el derecho fundamental a la libertad de expresión ampara al empleado de una empresa para hacer propaganda negativa de los productos de la misma? ¿El derecho a la libertad ideológica permite a un profesor de un centro privado enfocar su enseñanza en contra radicalmente del ideario de dicho centro?".

${ }^{17}$ Así lo hace ver A. López y LÓPEZ, Fundamentos de Derecho civil, cit., pp. 315-316, “démonos cuenta de que si salimos del Derecho privado, todo resulta más claro: nadie discute la imposibilidad de que un individuo sea privado de su derecho al voto por razón de su raza, precisamente en aplicación del principio de igualdad; todas las personas que utilizan un servicio público tienen derecho a que se les preste en paridad de condiciones; ningún funcionario público puede rehusar su actividad a ningún ciudadano; cualquier servidor público puede criticar el funcionamiento de la institución a la que pertenece, en ejercicio de su libertad de expresión; cualquier profesor de un centro público puede hacer ostensión de su particular ideología".

${ }^{18}$ Para t. FReIXEs SANJuÁn, Constitución y derechos fundamentales, Barcelona, 1992, p. 113, el art. 9.1 CE podría ser el precepto consagrador, en nuestro Ordenamiento Jurídico, de la eficacia horizontal de los derechos fundamentales. 
Respecto a dicha omisión se pronunció nuestro Tribunal Constitucional de forma muy clara en relación a una controversia laboral, en el FJ $4^{\circ}$ de su Sentencia 177/1988, 10 octubre ${ }^{19}$ : "ciertamente, el art. 53.1 del Texto constitucional tan sólo establece de manera expresa que los derechos fundamentales vinculan a los poderes públicos, pero ello no implica una exclusión absoluta de otros posibles destinatarios, dado que, como señala la STC 18/1984 (RTC 1984\18) (Fundamento jurídico $6 .^{\circ}$ ) «en un Estado social de Derecho no puede sostenerse con carácter general que el titular de tales derechos no lo sea en la vida social». De aquí que este Tribunal haya reconocido que los actos privados puedan lesionar los derechos fundamentales y que en estos supuestos los interesados pueden acceder a la vía de amparo si no obtienen la debida protección de los Jueces y Tribunales a los que el ordenamiento encomienda la tutela general de los mismos. Las relaciones entre particulares, si bien con ciertas matizaciones, no quedan, pues, excluidas del ámbito de aplicación del principio de igualdad, y la autonomía de las partes ha de respetar tanto el principio constitucional de no discriminación como aquellas reglas, de rango constitucional u ordinario, de las que se derive la necesidad de igualdad de trato. No cabe olvidar que el art. 1.1 C.E. propugna entre los valores superiores del ordenamiento jurídico la igualdad, y que el 9.2 encomienda a todos los poderes públicos promover las condiciones para que la igualdad del individuo y de los grupos en que se integra sean reales y efectivas".

Sin embargo, en el FJ $1^{\circ}$ de su STC 108/1989, 8 junio ${ }^{20}$, precisó que "el respeto de la igualdad ante la Ley se impone a los órganos del poder público, pero no a los sujetos privados, cuya autonomía está limitada sólo por la prohibición de incurrir en discriminaciones contrarias al orden público constitucional, como son, entre otras, las que expresamente se indican en el art. 14 CE". A la vista de tal afirmación, Bercovitz ${ }^{21}$ concluye que "el Tribunal viene a mantener que el principio de igualdad se impone con menor fuerza en el campo de la autonomía privada en comparación con la sumisión al mismo de los poderes públicos; concretamente, se impone en aplicación del orden público constitucional, prohibiéndose las discriminaciones contrarias al mismo. Esas discriminaciones, por otra parte, comprenden las enumeradas expresamente en el artículo $14 \mathrm{CE}$, pero no se limitan a ellas"22.

Aceptada, pues, una cierta virtualidad de los derechos fundamentales en las relaciones entre particulares, ha de reconocerse que los derechos fundamentales no son ilimitados ${ }^{23}$, siendo, en dicho ámbito, una cortapisa al ejercicio de los mismos la buena fe. Prima facie, podría resultar llamativo al lector que la buena fe adquiera rango constitucional, pero, si nos paramos a pensar, su ubicación en el Título Preliminar del Código civil, en concreto, en su art. 7.1, lo explica sobradamente.

16. Es evidente que los derechos fundamentales no operan, por igual, en todas las relaciones jurídicas inter privatos, de ahí que la Drittwirkung sólo puede encontrar una solución puramente casuística, precisándose, caso a caso y bajo las específicas circunstancias, la ponderación de los conflictos de derechos e intereses que subyacen en la horizontalidad conforme a un juicio de razonabilidad ${ }^{24}$.

En los conflictos horizontales entre particulares, el juez debe respetar, con sumo cuidado, la libertad individual, evitando una invasión desmesurada del principio de autonomía privada y del de libertad contractual, de ahí que la doctrina de la Drittwirkung deba reservarse, rigurosamente, a supuestos de grave infracción de derechos fundamentales que, agrediendo, razonablemente, valores esenciales y mínimos de la convivencia social, supongan un atentado al orden público constitucional.

\footnotetext{
${ }^{19}$ RTC $1988 \backslash 177$.

${ }^{20}$ RTC $1989 \backslash 108$.

${ }^{21}$ R. BERCOVITZ, "El principio de igualdad y Derecho privado", $A D C, 1990$, p. 412.

${ }^{22}$ Comparte dicha opinión A. LÓPEZ y LÓPEZ, Fundamentos de Derecho civil, cit., p. 318, pues "inherente es al propio concepto de autonomía privada el predominio de la voluntad individual sobre la igualdad. Lo que no se permite es que la autonomía privada produzca discriminaciones manifiestas, basadas en las que expresamente prohíbe el artículo 14 de la Constitución: nacimiento, raza, sexo, religión u opinión, o derivadas de circunstancias personales o sociales que tengan la suficiente transcendencia social para afectar, precisamente, al orden público, y siempre atendida la naturaleza del concreto acto de autonomía considerado, y las circunstancias del mismo".

${ }^{23}$ STC 88/1985, 19 julio (RTC 1985, 88).

${ }^{24}$ V. A. CARRASCO PERERA, "El juicio de razonabilidad en la justicia constitucional”, $R E D C$, 1984, pp. 39-106.
} 


\section{EI Derecho contractual antidiscriminatorio}

\section{El principio de no discriminación como límite de la libertad contractual}

17. En el moderno Derecho civil la autonomía privada no es sólo un valor en sí mismo, sino un instrumento a través del cual se ejercen los derechos constitucionales en el escenario socioeconómico. La celebración de un contrato es el modo a través del cual el sujeto desarrolla su personalidad en sus relaciones con otros individuos buscando en aquél prestaciones económicas o puede que extrapatrimoniales.

18. Desde siempre, el Derecho contractual ha sido la materia del ámbito privado menos permeable a los principios y valores constitucionales, sin embargo, a nuestro juicio, no puede seguir resistiéndose a que la libertad de pactar sea incluida en la obligada lectura constitucional de nuestro decimonónico Código y de las leyes civiles extracodiciales ${ }^{25}$.

Partiéndose de que la autonomía privada no es absoluta, pues no supone ni mucho menos hacer lo que a uno le venga en gana, en el Derecho contractual postconstitucional aquélla encontró limitaciones impuestas por el poder público (pensemos en los contratos de arrendamiento) con el fin de garantizar intereses sociales o comunitarios. Es claro que la libertad contractual no sólo permite satisfacer intereses particulares, sino que también ha de perseguir fines para la sociedad. Por ello, encuentra un límite en el orden público, tras el cual se encuentra la necesidad de garantizar el goce de los derechos fundamentales de la persona también en el marco de los negocios jurídicos privados. La autodeterminación permite actuar en razón de intereses propios pero el comportamiento negocial es legítimo sólo si cuenta con la aceptación social. En definitiva, el contrato queda sujeto a los valores y principios constitucionales, a los derechos fundamentales de la persona y a su dignidad.

Ahora bien, si no puede hablarse de la absoluta intangibilidad de la autonomía contractual, tampoco puede aceptarse su completa aniquilación. Ello es, según creemos, incuestionable.

\section{Los mecanismos legales de tutela}

19. Con el fin de lograr una sociedad integradora e inclusiva y, por consiguiente, justa, se han dictado en los últimos años diversas normas antidiscriminatorias en aras de lograr un trato igualitario de las personas, normas que, hoy día, constituyen un importante corpus heterorregulador del mercado, que, en materia contractual, pretende depurarlo de absurdos prejuicios y estereotipos a la hora de acceder a bienes y servicios. La prohibición de discriminación es, en nuestros días, una regla del Derecho de los contratos.

20. Sin duda alguna la Unión Europea ha jugado y juega un rol fundamental en la configuración del principio de no discriminación e igualdad de trato como un principio general del ordenamiento comunitario. Lo ha incorporado a sus Tratados constitutivos e intenta crear a través de un importante paquete de Directivas antidiscriminatorias ${ }^{26}$, un marco general para combatir las inaceptables desigualdades de trato en el seno de la Unión. Además, contamos hoy día con un gran número de recomendaciones y de

${ }^{25} \mathrm{Al}$ respecto, vid. G. ALPA, "Libertà contrattuale e tutela costituzionale”, Riv. crit. Dir. priv., 1995, pp. 39 y ss.; F. GALGANO, "Libertà contrattuale e giustizia del contratto", Contratto e impresa. Europa, 2005, pp. 509 y ss.; M. ESPosito, Profili costituzionali dell'autonomia privata, Padova, 2003; F. MACARIO, "L'autonomia privata nella cornice costituzionale: per una giurisprudenza evolutiva e coraggiosa”, Questione giustizia, 2016, 4, pp. 52-76; E. NAVARRETTA, "Il contratto 'democratico' e la giustizia contrattuale”, Riv. Dir. civ., 2016, pp. 1262-1291.

${ }^{26}$ Para un detenido estudio, vid. D. LA RocCA, Eguaglianza e libertà contrattuale nel Diritto europeo, Le discriminazioni nei rapporti di consumo, Torino, 2008; P. CHIECO, "Le nuove Direttive comunitarie sul divieto di discriminazione", Riv. it. Dir. lav., 2002, I, pp. 75 y ss.; L. CALAFÀ, "Le Direttive antidiscriminatorie di 'nuova generazione': il recepimento italiano", Studium Iuris, 2004, pp. 873 y ss.; C. FAVILLI, La non discriminazione nell'Unione europea, Bologna, 2008; L. CALAFÀ/ D. GOTTARDI, Il Diritto antidiscriminatorio tra teoria e prassi applicativa, Roma, 2009; M. RANIERI: "Direttive antidiscriminatorie di seconda generazione e Corte di Giustizia dell'Ue: alcune questioni problematiche”, Rivista giuridica del lavoro e della previdenza sociale, 2012 , vol. 63, fasc. 1, pp. 165-210. 
resoluciones del Parlamento Europeo, así como con una vasta jurisprudencia del Tribunal de Justicia, encargado de ir dando forma concreta, en cada caso enjuiciado, al principio de igualdad de trato.

Al igual que en Estados Unidos la lucha contra la discriminación tuvo inicialmente un alcance limitado centrado en el racismo (después se ampliaría a otros motivos en el Título VII de la Civil Rights Act de 1964 así como en normas federales), la primera previsión normativa comunitaria también, la discriminación por razón de sexo y, además, en un determinado ámbito, el del empleo: en este sentido, el art. 119 del Tratado de Roma de 1957 contemplaba la igualdad entre mujeres y hombres en materia retributiva. Décadas después, el Tratado de Ámsterdam supuso un hito al reforzar el compromiso europeo con la igualdad entre hombres y mujeres pero con una visión más global, la transversalidad de género (mainstreaming). Más tarde, el Tratado de Lisboa reafirmó el principio de igualdad y no discriminación, incluyéndolo entre los valores y objetivos de la Unión.

La gran preocupación del legislador comunitario por impedir situaciones discriminatorias por razones relativas a las condiciones personales del contratante se detecta, con suma facilidad, apenas se hace lectura del art. 19 del Tratado de Funcionamiento de la Unión Europea (antiguo art. 13 del Tratado constitutivo), el cual amplía sus competencias facultando al Consejo a adoptar decisiones al respecto:

“1. Sin perjuicio de las demás disposiciones de los Tratados y dentro de los límites de las competencias atribuidas a la Unión por los mismos, el Consejo, por unanimidad con arreglo a un procedimiento legislativo especial, y previa aprobación del Parlamento Europeo, podrá adoptar acciones adecuadas para luchar contra la discriminación por motivos de sexo, de origen racial o étnico, religión o convicciones, discapacidad, edad u orientación sexual.

2. No obstante lo dispuesto en el apartado 1, el Parlamento Europeo y el Consejo podrán adoptar, con arreglo al procedimiento legislativo ordinario, los principios básicos de las medidas de la Unión de estímulo, con exclusión de toda armonización de las disposiciones legales y reglamentarias de los Estados miembros, para apoyar las acciones de los Estados miembros emprendidas con el fin de contribuir a la consecución de los objetivos enunciados en el apartado 1".

Y, como ya vimos, la Carta de los derechos fundamentales de la Unión Europea dedica varios preceptos a la igualdad. En su art. 21 prohíbe toda discriminación y, en particular, la ejercida por razón de sexo, raza, color, orígenes étnicos o sociales, características genéticas, lengua, religión o convicciones, opiniones políticas o de cualquier otro tipo, pertenencia a una minoría nacional, patrimonio, nacimiento, discapacidad, edad u orientación sexual; además, prohíbe toda discriminación por razón de nacionalidad en el ámbito de aplicación de los Tratados y sin perjuicio de sus disposiciones particulares. La Carta, en su art. 23, dispone que la igualdad entre mujeres y hombres deberá garantizarse en todos los ámbitos, inclusive en materia de empleo, trabajo y retribución. El principio de igualdad no impide el mantenimiento o la adopción de medidas que supongan ventajas concretas en favor del sexo menos representado.

En el Derecho derivado (que, por efecto de sus fines de armonización, después resulta incorporado a los Derechos nacionales), las primeras Directivas antidiscriminación se circunscribieron al ámbito laboral ${ }^{27}$. Sin embargo, la Directiva 2000/43/CE del Consejo, de 29 de junio, relativa a la aplicación

\footnotetext{
${ }^{27}$ Vid. la Directiva 75/117/CEE del Consejo, de 10 de febrero de 1975, relativa a la aproximación de las legislaciones de los Estados Miembros que se refieren a la aplicación del principio de igualdad de retribución entre los trabajadores masculinos y femeninos; la Directiva 76/207/CEE del Consejo, de 9 de febrero de 1976, relativa a la aplicación del principio de igualdad de trato entre hombres y mujeres en lo que se refiere al acceso al empleo, a la formación y a la promoción profesionales, y a las condiciones de trabajo; la Directiva 79/7/CEE del Consejo, de 19 de diciembre de 1978, relativa a la aplicación progresiva del principio de igualdad de trato entre hombres y mujeres en materia de seguridad social; la Directiva 86/378/CEE del Consejo, de 24 de julio de 1986, relativa a la aplicación del principio de igualdad de trato entre hombres y mujeres en los regímenes profesionales de seguridad social; la Directiva 86/613/CEE del Consejo, de 11 de diciembre de 1986, relativa a la aplicación del principio de igualdad de trato entre hombres y mujeres que ejerzan una actividad autónoma, incluidas las actividades agrícolas, así como sobre la protección de la maternidad; la Directiva 92/85/CEE del Consejo, de 19 de octubre de 1992, relativa a la aplicación de medidas para promover la mejora de la seguridad y de la salud en el trabajo de la trabajadora embarazada, que haya dado a luz o en período de lactancia (décima Directiva específica con arreglo al apartado 1 del artículo 16 de la Directiva 89/391/CEE) y la Directiva 97/80/CE del Consejo, de 15 de diciembre de 1997, relativa a la carga de la prueba en los casos de discriminación por razón de sexo. Tras el Tratado de Ámsterdam, citamos la Directiva del Consejo 2000/78/CE, de 27 de noviembre de 2000, relativa al establecimiento de un marco general para la igualdad de trato en el empleo y la ocupación; la
} 
del principio de igualdad de trato de las personas independientemente de su origen racial o étnico, en su art. 3.1.h) dispone: "Dentro de los límites de las competencias atribuidas a la Comunidad la presente Directiva se aplicará a todas las personas, por lo que respecta tanto al sector público como al privado, incluidos los organismos públicos, en relación con: h) el acceso a bienes y servicios disponibles para el público y la oferta de los mismos, incluida la vivienda".

Pero es, sin duda, la Directiva del Consejo 2004/113/CE, de 13 de diciembre, por la que se aplica el principio de igualdad de trato entre hombres y mujeres al acceso a bienes y servicios y su suministro, la que entra de lleno en el ámbito de la contratación y en la discriminación por razón de sexo a la hora de acceder a los mismos. En su art. 3, relativo a su ámbito de aplicación, dispone:

"1. Dentro de los límites de los poderes conferidos a la Comunidad, la presente Directiva se aplicará a todas las personas que suministren bienes y servicios disponibles para el público, con independencia de la persona de que se trate, tanto en lo relativo al sector público como al privado, incluidos los organismos públicos, y que se ofrezcan fuera del ámbito de la vida privada y familiar, y a las transacciones que se efectúen en ese contexto.

2. La presente Directiva no afectará a la libertad de la persona a la hora de elegir a la otra parte contratante, siempre y cuando dicha elección no se base en el sexo de la persona contratante.

3. La presente Directiva no se aplicará al contenido de los medios de comunicación o de la publicidad, ni a la educación.

4. La presente Directiva no se aplicará a asuntos relacionados con el empleo y la ocupación. No se aplicará a asuntos relacionados con el trabajo por cuenta propia, en la medida en que dichos asuntos estén cubiertos por otros actos legislativos comunitarios".

Repare el lector que se requiere que los bienes y servicios estén disponibles al público, de modo que deja fuera las transacciones que tengan lugar en el seno de la vida privada o familiar, a las que la norma comunitaria no resulta de aplicación, como tampoco al contenido de los medios de comunicación o de la publicidad ni a la educación, ni a los asuntos relacionados con el empleo y la ocupación.

En su art. 4.5. dispone: "La presente Directiva no prohíbe las diferencias de trato cuando la prestación de bienes y servicios de forma exclusiva o principal a las personas de uno de los sexos esté justificada por un propósito legítimo y los medios para lograr ese propósito sean adecuados y necesarios".

La Resolución del Parlamento Europeo, de 20 de mayo de 2008, sobre los progresos realizados respecto a la igualdad de oportunidades y la no discriminación en la Unión Europea (transposición de las Directivas 2000/43/CE y 2000/78/CE), pedía a los Estados miembros que, en su práctica legislativa, tuvieran debidamente en cuenta los varios motivos de discriminación que se mencionan en el antes citado art. 21 de la Carta de los derechos fundamentales de la Unión Europea.

Es indudable que las normas comunitarias se han preocupado especialmente por los abusos en los contratos con consumidores y ello porque el consumidor reviste una enorme importancia al ser pieza clave en el objetivo de construir un mercado único y de libre competencia. El control legal sobre el contenido del contrato con el fin de proteger al contratante más débil se detecta, claramente, en materias como el contrato de crédito al consumo o el de viajes combinados. Con tales limitaciones de la autonomía privada no se persigue su reducción, sino la remoción de obstáculos al mercado interior.

Pero si bien las primeras intervenciones legislativas de la Unión Europea en materia contractual respondieron a fines puramente mercantilistas (junto a los laborales), las sucesivas han intentado promover los valores de la persona en todos los ámbitos, de ahí la progresiva incidencia del principio de no discriminación en el contrato.

Directiva 2002/73/CE del Parlamento Europeo y del Consejo, de 23 de septiembre de 2002, que modifica la Directiva 76/207/ CEE del Consejo relativa a la aplicación del principio de igualdad de trato entre hombres y mujeres en lo que se refiere al acceso al empleo, a la formación y a la promoción profesionales, y a las condiciones de trabajo; la Directiva 2006/54/CE del Parlamento Europeo y del Consejo de 5 de julio de 2006 relativa a la aplicación del principio de igualdad de oportunidades e igualdad de trato entre hombres y mujeres en asuntos de empleo y ocupación (refundición) y la Directiva 2010/41, de 7 de julio de 2010, sobre la aplicación del principio de igualdad de trato entre hombres y mujeres que ejercen una actividad autónoma y por la que se deroga la Directiva 86/613/CEE del Consejo. 
Dicha preocupación del legislador comunitario por la regulación del principio general de no discriminación y de las medidas específicas para garantizar la efectividad del mismo más allá del ámbito laboral resulta evidente en la propuesta de Directiva del Consejo por la que se aplica el principio de igualdad de trato entre las personas independientemente de su religión o convicciones, discapacidad, edad u orientación sexual ${ }^{28}$, la cual, tal y como expresa en su Exposición de Motivos, pretende crear un marco para la prohibición de la discriminación por estos motivos y establece un nivel mínimo homogéneo de protección en la Unión Europea para las personas que han sufrido una discriminación de este tipo.

21. Entre las iniciativas académicas de revisión del Derecho contractual europeo ${ }^{29}$, la prohibición de discriminar a la otra parte contratante se contempló en los Principles of the Existing EC Contract Law (Acquis Princples), en concreto, en el capítulo 3 (arts. 3:101 a 3:203) ${ }^{30}$, así como en el Draft Common Frame of Reference del Study Group on a European Civil Code, en el capítulo 2 del Libro 2 (arts. 2:101 a 2:105) ${ }^{31}$, que reconoce explícitamente el "right not to be discriminated against", si bien lo circunscribe a la discriminación por razón de sexo (rectius: género) y de origen étnico o racial y a los bienes o servicios disponibles al público, como puede comprobarse: "Art. 2:101. Right not to be discriminated against. A person has a right not to be discriminated against on the grounds of sex or ethnic or racial origin in relation to a contract or other juridical act the object of which is to provide access to, or supply, goods, other assets or services which are available to the public".

22. En el ámbito interno, la normas comunitarias antidiscriminatorias se incorporan a nuestro Derecho nacional ${ }^{32}$ a través de la Ley 6/2003, de 30 de diciembre, de medidas fiscales, administrativas y del orden social y la Ley Orgánica 3/2007, de 22 marzo, para la igualdad efectiva de mujeres y hombres.

En cuanto a la discapacidad, si bien son destacables como normas antidiscriminatorias la Ley $51 / 2003$, de 2 de diciembre, de igualdad de oportunidades, no discriminación y accesibilidad universal de las personas con discapacidad, la cual preveía el establecimiento de un régimen de infracciones y sanciones que se materializó en la Ley 49/2007, de 26 de diciembre, ambas derogadas junto a la Ley 13/1982, de 7 de abril, de integración social de las personas con discapacidad, por el Real Decreto Legislativo 1/2013, de 29 de noviembre, por el que se aprueba el Texto Refundido de la Ley General de derechos de las personas con discapacidad y de su inclusión social, en el que las tres leyes citadas pasan a integrarse, es innegable que las mayores intervenciones legislativas tienen lugar a partir de la ratificación por España (y por la propia Unión Europea ${ }^{33}$ ) de la Convención de Naciones Unidas de las personas con discapacidad ${ }^{34}$, la cual ha venido a cambiar radicalmente el panorama jurídico en este ámbito al introducir un nuevo concepto de discapacidad, la cual pasa a ser considerada una cuestión de derechos humanos y no como una preocupación en materia de bienestar social, y al contemplar medidas de no discriminación y de acción positiva para lograr la efectiva tutela de las personas con discapacidad.

\footnotetext{
${ }^{28}$ I. HERBOSA MARTÍNEZ, "Una primera aproximación a la propuesta de Directiva del Consejo por la que se aplica el principio de igualdad de trato entre las personas independientemente de su religión o convicciones, discapacidad, edad u orientación sexual", Unión Europea Aranzadi, núm. 5, 2020.

${ }^{29}$ Para un mayor estudio, vid. S. NAVAS NAVARRO, "El principio de no discriminación en el Derecho contractual europeo", $A D C, 2008$, pp. 1475-1490.

${ }^{30}$ Principles of the Existing EC Contract Law (acquis Principles), Munich, 2007, pp. 105 y ss.

${ }^{31}$ Principles. Definitions and model rules of European Private Law. Draft Common Frame of reference (DCFr), Interim Outline Edition, Munich, 2008, pp.108 y ss.

Para un detenido estudio, vid. s. tommasi, "La no discriminazione nel 'Draft Commmon Frame o Reference", Riv. crit. Dir. priv., 2011, pp. 119 y ss.

${ }^{32}$ En el Derecho alemán, la transposición de las Directivas comunitarias se realizó a través de la Allgemeines Gleichbehandlungsgesetz ( $A G G$ ) de 14 de agosto de 2006, la cual se aplica tanto a las cuestiones relativas al empleo como a las prestaciones del sistema público de la Seguridad Social y a la educación, así como a la contratación de bienes y servicios que se encuentren a disposición del público, incluso la vivienda.

${ }^{33}$ Decisión 2010/48/CE del Consejo relativa a la celebración, por parte de la Comunidad Europea, de la Convención de las Naciones Unidas sobre los derechos de las personas con discapacidad.

${ }^{34}$ BOE núm. 96, de 21 de abril de 2008, entrando en vigor, en España, el día 3 de mayo.
} 
Sus principios de no discriminación, participación e inclusión social, igualdad de oportunidades y accesibilidad se incorporaron a nuestro ordenamiento a través de la Ley 26/2011, de 1 de agosto, de adaptación normativa a la Convención Internacional sobre los derechos de las personas con discapacidad.

El art. 5.2 del Convenio de Nueva York dispone que "los Estados Partes prohibirán toda discriminación por motivos de discapacidad y garantizarán a todas las personas con discapacidad protección legal igual y efectiva contra la discriminación por cualquier motivo".

Por su parte, el art. 25, e), relativo a la salud, dispone que "los Estados Partes reconocen que las personas con discapacidad tienen derecho a gozar del más alto nivel posible de salud sin discriminación por motivos de discapacidad. Los Estados Partes adoptarán las medidas pertinentes para asegurar el acceso de las personas con discapacidad a servicios de salud que tengan en cuenta las cuestiones de género, incluida la rehabilitación relacionada con la salud. En particular, los Estados Partes: e) Prohibirán la discriminación contra las personas con discapacidad en la prestación de seguros de salud y de vida cuando éstos estén permitidos en la legislación nacional, y velarán por que esos seguros se presten de manera justa y razonable".

Pues bien, tras detectarse numerosas prácticas discriminatorias por razón de la discapacidad en la contratación de seguros privados de asistencia sanitaria, el art. 14 de la citada Ley 26/2011 introdujo en la Ley 50/1980, de 8 de octubre, de contrato de seguro, conforme al mandato del art. 25, e) de la Convención, la Disposición adicional $4^{\mathrm{a}}$, con el siguiente tenor literal:

"Disposición adicional cuarta. No discriminación por razón de discapacidad.

No se podrá discriminar a las personas con discapacidad en la contratación de seguros. En particular, se prohíbe la denegación de acceso a la contratación, el establecimiento de procedimientos de contratación diferentes de los habitualmente utilizados por el asegurador o la imposición de condiciones más onerosas, por razón de discapacidad, salvo que se encuentren fundadas en causas justificadas, proporcionadas y razonables, que se hallen documentadas previa y objetivamente".

El giro de modelo que se produce con la Convención neoyorquina, del rehabilitador al social o de derechos humanos provoca que la discapacidad deba dejar de asociarse a la enfermedad para considerarla una deficiencia física, mental, intelectual o sensorial a largo plazo que puede presentar una persona que, al interactuar con barreras de diversa índole, le impiden su participación plena y efectiva en la sociedad, en igualdad de condiciones con las demás (art. 1, pfo. $2^{\circ}$ ). Por tanto, la discapacidad, en el ámbito de los seguros privados de asistencia sanitaria, no está necesariamente relacionada con el estado de salud previo a la contratación de la póliza. Sin embargo, las compañías aseguradoras siguen vinculando, erróneamente, discapacidad y enfermedad.

Una duda que suscita dicha Disposición adicional $4^{\mathrm{a}}$ es a quién considera el legislador una persona con discapacidad, puesto que, si bien tenemos claro quién lo es para la Convención, ello no encaja con lo entendido en la práctica, en la que se exige un certificado administrativo de discapacidad de un grado igual o superior al $33 \%{ }^{35}$ (por tanto, con un $32 \%$ no lo es, aunque encuentre barreras que le impidan su plena participación social en igualdad de condiciones que los demás), lo que, a nuestro juicio, no se ajusta ni a la definición ni al espíritu de dicho Tratado internacional ${ }^{36}$.

\footnotetext{
${ }^{35}$ Vid., Real Decreto 1971/1999, de 23 de diciembre, de procedimiento para el reconocimiento, declaración y calificación del grado de discapacidad.

${ }^{36}$ En opinión de I. VIVAS TESÓN, "El ejercicio de los derechos de la personalidad de la persona con discapacidad», en Claves para la adaptación del Ordenamiento jurídico privado a la Convención de Naciones Unidas en materia de discapacidad, DE SALAS y MAYOR DEL HOYO (dirs.), Valencia, p. 409: “en Derecho español existe una clara disfunción o desajuste pues la imprescindible exigencia normativa de un reconocimiento formal de discapacidad con un grado mínimo del $33 \%$ no casa adecuadamente con la definición de discapacidad contenida en el art. 1, pfo. $2^{\circ}$ de la Convención ("las personas con discapacidad incluyen a aquellas que tengan deficiencias físicas, mentales, intelectuales o sensoriales a largo plazo que, al interactuar con diversas barreras, puedan impedir su participación plena y efectiva en la sociedad, en igualdad de condiciones con las demás", de modo que la discapacidad no se presenta por deficiencias concretas de las personas, sino por diversas barreras que pueden ser sociales, físicas, actitudinales $o$ jurídicas, lo que permite establecer como objetivo la eliminación de las barreras existentes de toda índole) y, por tanto, creemos que no se ajusta al modelo social de la misma como sí, en cambio, el art. 2.a) del Real Decreto Legislativo 1/2013, de 29 de noviembre, por el que se aprueba el Texto Refundido de la Ley General de derechos de las personas con discapacidad y de su inclusión social,
} 
Unos años más tarde y fruto de la lucha del movimiento asociativo durante no pocas décadas, la Disposición final $1^{\text {a }}$ de la Ley 4/2018, de 11 de junio, por la que se modifica el Texto Refundido de la Ley General para la Defensa de los Consumidores y Usuarios y otras leyes complementarias, aprobado por Real Decreto Legislativo 1/2007, de 16 de noviembre, añadió a dicha norma una Disposición Adicional única, con el siguiente texto:

"Disposición adicional única. Nulidad de determinadas cláusulas.

1. Serán nulas aquellas cláusulas, estipulaciones, condiciones o pactos que excluyan a una de las partes, por tener VIH/SIDA u otras condiciones de salud.

2. Asimismo, será nula la renuncia a lo estipulado en esta disposición por la parte que tenga VIH/ SIDA u otras condiciones de salud".

Asimismo, incluye una Disposición final 4a:

"Disposición final cuarta. Ampliación a otras enfermedades.

El Gobierno, en el plazo de un año, presentará un proyecto de ley en el que determinará la aplicación de los principios de esta ley a otras enfermedades respecto a las que pueda considerarse que se aplican los mismos efectos excluyentes en las relaciones jurídicas".

A la espera aún de que se cumpla dicha promesa aun extemporáneamente, en la expresión "otras condiciones de salud" entendemos que, entre éstas, deben ser incluidas la diabetes y el Covid-19.

La misma Ley 4/2018, de 11 de junio, modifica también la Ley de contrato de seguro de 1980, a la que añade la Disposición adicional $5^{\mathrm{a}}$, fiel copia de la $4^{\mathrm{a}}$ sobre no discriminación por razón de discapacidad que antes hemos reproducido:

"Disposición adicional quinta. No discriminación por razón de VIH/SIDA u otras condiciones de salud.

No se podrá discriminar a las personas que tengan VIH/SIDA u otras condiciones de salud. En particular, se prohíbe la denegación de acceso a la contratación, el establecimiento de procedimientos de contratación diferentes de los habitualmente utilizados por el asegurador o la imposición de condiciones más onerosas, por razón de tener VIH/SIDA u otras condiciones de salud, salvo que se encuentren fundadas en causas justificadas, proporcionadas y razonables, que se hallen documentadas previa y objetivamente".

23. Sabemos que el seguro es un tipo contractual singular, sobre todo, cuando se trata de un seguro de persona (asistencia sanitaria o vida), en el que el estado de salud del asegurado es clave para la valoración del riesgo y consiguiente determinación de las condiciones contractuales, entre ellas, la fijación de la prima.

Según el art. 10, pfo. $1^{\circ}$, de la Ley 50/1980, de 8 de octubre, del contrato de seguro, "el tomador del seguro tienen el deber, antes de la conclusión del contrato, de declarar al asegurador, de acuerdo con el cuestionario que éste le someta, todas las circunstancias por él conocidas que puedan influir en la valoración del riesgo. Quedará exonerado de tal deber si el asegurador no le somete cuestionario o cuando, aun sometiéndoselo, se trate de circunstancias que puedan influir en la valoración del riesgo y que no estén comprendidas en él”. En sus párrafos $2^{\circ}$ y $3^{\circ}$ se contempla la posibilidad de que la aseguradora resuelva el contrato o reduzca el pago de la prestación convenida en caso de reserva o inexactitud en la contestación al cuestionario, pudiendo, incluso, liberarse del pago de la misma si media dolo o culpa grave del tomador del seguro.

así como el art. 25 del Código penal en su redacción de 2015. Para mayor confusión, dicho certificado administrativo sigue exigiéndose para algunos actos jurídicos pero, en cambio, no para otros, como, por ejemplo, en la Ley de Propiedad Horizontal, que en su art. 10.1.b) reconoce automáticamente a los mayores de 70 años su condición de personas con discapacidad. A la vista de ello, me pregunto: hoy día, en el Ordenamiento jurídico, ¿quién es, desde el punto de vista jurídico, una persona con discapacidad?».

Según el Proyecto de Ley por la que se reforma la legislación civil y procesal para el apoyo a las personas con discapacidad en el ejercicio de su capacidad jurídica, cuya remisión a las Cortes Generales fue acordada en Consejo de Ministros el pasado 7 de julio de 2020 y actualmente en tramitación, persona con discapacidad es aquélla que precisa medidas de apoyo para para el adecuado ejercicio de su capacidad jurídica (art. 249), pero no se proporciona ninguna definición, la cual, a la vista de la disparidad de conceptos normativos existentes en la actualidad en nuestro Ordenamiento jurídico, sería muy necesaria. 
A nuestro juicio, reviste enorme interés práctico la Sentencia de la Audiencia Provincial de Murcia (Sección $5^{\text {a }}$ ) 17 diciembre $2019^{37}$, en la que se enjuicia el caso de una persona de 41 años con diabetes mellitus tipo 2, la cual no suponía incapacidad o defecto físico ni le impedía trabajar, quien suscribió un contrato de seguro de amortización de préstamo en cuyo cuestionario médico se preguntó al asegurado si se encontraba en buen estado de salud, a lo que respondió que sí, pese a que en ese momento ya padecía diabetes. El asegurado interpuso demanda contra la aseguradora solicitando el pago de la indemnización correspondiente al seguro que cubría, en caso de incapacidad permanente, el pago de las cuotas del préstamo hipotecario, la cual fue desestimada por el Juzgado de Primera Instancia al considerar la existencia de dolo. Interpuesto recurso de apelación por la parte actora, la Audiencia Provincial revoca la sentencia y estima la demanda porque considera que el asegurado no incumplió su deber de veracidad al responder al cuestionario médico, puesto que éste no existió, sino tres preguntas: ¿si se encontraba en buen estado de salud? a lo que respondió que sí, ¿qué si padecía alguna incapacidad o defecto físico? a lo que respondió que no, y ¿si tenía plena capacidad de trabajo? a lo que respondió que sí.

La Audiencia Provincial cita la doctrina jurisprudencial según la cual no toda inexactitud en la respuesta al cuestionario determina la existencia de dolo que exonere a la aseguradora del pago de la prestación. Por el contrario, es preciso que lo declarado sea relevante para la valoración del riesgo, de tal forma que su ocultación hubiera influido en las condiciones en que se contrató el seguro y en la decisión del asegurador de aceptar el contrato. Y añade: "Y no hay que olvidar que en este tipo de contratos en el que es, como señala la propia sentencia apelada, práctica bancaria generalizada el de acompañar a la concesión del préstamo un seguro de vida o de amortización, que se ofrece simultáneamente, tanto para asegurar el fin de la operación financiera como para aumentar el volumen de negocio y cartera de clientes de las entidades aseguradoras pertenecientes a su propio grupo empresarial, por lo que no se trata de un seguro celebrado a solicitud del propio asegurado, en el que se busca dolosamente un enriquecimiento injusto, ocultando alguna enfermedad o defecto. Como es el caso, como el presente, en el que la entidad financiera prácticamente exige el seguro y se limita a hacer unas preguntas generales, en lugar de un cuestionario médico revelador. Dándose el caso que el seguro de amortización del préstamo, formalizado el 5 de julio de 2002, lo era de una duración de 240 meses o sea 20 años. No produciéndose el dictamen propuesta de la incapacidad permanente hasta el 12 de marzo de 2014, es decir, trascurrido ya 12 años desde la firma del préstamo y del seguro. Dándose la circunstancia de que el demandante tenía en el momento de la contratación 41 años, en cuanto nacido el 31/12/1960. De tal forma que no se puede apreciar la existencia de engaño alguno, cuando una persona de 41 años, con plena capacidad laboral, manifiesta no padecer enfermedad alguna, si se trata de diabetes en el que a esa edad todavía no ha manifestado ningún impedimento, pues es norma de la experiencia que la diabetes más que una enfermedad es un defecto orgánico que no produce dolor ni molestia alguna, sino que lo que produce a lo largo del tiempo es un deterioro orgánico del cuerpo, sobre todo en riñón, miembros y ojos, como es el caso presente este último, y ello solo o en la medida en que dicha diabetes no es controlada por quien la padece.

Así, en el caso presente no se producen los efectos de dicho defecto silente, que constituye la diabetes hasta muchos años después de la contratación del seguro y ello más por la falta de control de los niveles de glucosa en sangre que por dicho defecto orgánico.

De tal forma que habría que preguntarse si el exacto conocimiento de que el demandante padecía ya diabetes en el momento del contrato a la edad de 41 años, hubiera impedido la realización de un contrato por un tiempo de duración en que no era previsible, con un adecuado control de dicho padecimiento, causara la retinopatía diabética que ha limitado su agudeza visual y ha dado lugar a la declaración de la incapacidad, ya que la evolución de la diabetes no siempre determina la existencia de la retinopatía, menos aun si la misma está controlada, y desde luego no cabe pensar que el demandante voluntariamente haya pretendido quedarse medio ciego, sino que ha sido fruto de su bajo nivel socioeconómico y cultural, como única explicación a su falta de control de dicha enfermedad. Lo que nos lleva a considerar que su no declaración carecía de dolo y no hubiera influido en la contratación del seguro realizado en interés de la compañía contratante. En consecuencia, procede estimar el recurso" (FJ $\left.2^{\circ}\right)$.

${ }^{37}$ JUR $2020 \backslash 87577$. 
En consecuencia, la Audiencia Provincial condena a la aseguradora a abonar a la entidad financiera las cantidades pendientes de amortizar del préstamo hipotecario, así como a pagar al demandante las abonadas indebidamente.

Con claridad inequívoca, el legislador incluye en la regulación de seguros privados dos normas antidiscriminatorias destinadas a grupos de personas históricamente desfavorecidas $\mathrm{y}$, por consiguiente, marginadas socialmente, las personas con discapacidad y las personas con VIH/SIDA ${ }^{38}$.

El sector asegurador ya ha reaccionado adecuando el contenido de sus cuestionarios de salud al Covid-19/SARS-CoV-2 y al escenario de riesgos que estamos viviendo por causa de la pandemia del coronavirus. Desconocemos si en las condiciones generales de los seguros privados, tanto de salud como de vida, van a empezar a excluir de la cobertura de la póliza a las personas que se hayan infectado o hayan desarrollado el Covid-19 (téngase en cuenta que entre ellas pueden hallarse profesionales sanitarios), como ya sucediera con el VIH/SIDA.

24. Otra cuestión común a ambas Disposiciones Adicionales $4^{\mathrm{a}}$ y $5^{\mathrm{a}}$ añadidas a la Ley 50/1980, de 8 de octubre, del contrato de seguro es su inciso final: "salvo que se encuentren fundadas en causas justificadas, proporcionadas y razonables, que se hallen documentadas previa y objetivamente", previsión que habilita a las compañías aseguradoras a rechazar la contratación o imponer condiciones más onerosas por razón de discapacidad, VIH/SIDA u "otras condiciones de salud". Ello provoca que tras un trato diferenciado aparentemente "fundado" por parte de la compañía exista, en realidad, un trato discriminatorio. En la práctica cotidiana aseguradora, intuimos que, ante la ausencia de mecanismos de control, es lo que sucede, convirtiendo en papel mojado las previsiones normativas antidiscriminatorias en materia de seguros privados.

25. El art. 53.2 de la CE establece que cualquier ciudadano puede recabar la tutela del derecho de igualdad ante la Ley recogido en su art. 14, ante los tribunales ordinarios, por un procedimiento basado en los principios de preferencia y sumariedad. El mismo precepto contempla también que cualquier ciudadano puede acudir ante el Tribunal Constitucional a través de un recurso de amparo.

Por su parte, el Defensor del Pueblo, en virtud del art. 54 de la CE, tiene competencias para la defensa de los derechos recogidos en el Título I de la Constitución, entre ellos, el del art. 14.

26. En cuanto a la tutela penal ante un trato discriminatorio ${ }^{39}$, destacamos la tipificación por el Código penal de los delitos relativos al ejercicio de los derechos fundamentales y libertades públicas en sus arts. 510 y ss. En concreto, el art. $510.1^{\circ}$ recoge el delito de odio en los siguientes términos:

“1. Serán castigados con una pena de prisión de uno a cuatro años y multa de seis a doce meses:

a) Quienes públicamente fomenten, promuevan o inciten directa o indirectamente al odio, hostilidad, discriminación o violencia contra un grupo, una parte del mismo o contra una persona determinada por razón de su pertenencia a aquél, por motivos racistas, antisemitas u otros referentes a la ideología, religión o creencias, situación familiar, la pertenencia de sus miembros a una etnia, raza o nación, su origen nacional, su sexo, orientación o identidad sexual, por razones de género, enfermedad o discapacidad.

${ }^{38}$ Vid. L. C. PÉREZ BUENo, La discriminación por razones de discapacidad en la contratación de seguros, Colección CERMI, 2004, núm. 11; C. GonZÁLEZ CARRASCO, "La discriminación por razón de discapacidad en los seguros privados de asistencia sanitaria", Revista CESCO de Derecho de Consumo, 2013, núm. 8, pp. 408-419 y "La vida no va de cromosomas (a propósito del aseguramiento de la sanidad privada de los discapacitados", íbidem, 2015; P. DomínguEz MARTínEz, "La contratación del seguro de asistencia sanitaria y las limitaciones de los derechos de determinados asegurados", Revista CESCO de Derecho de Consumo, 2013, núm. 8; FUNDACIÓN ONCE, El sector seguros y las personas con discapacidad y sus familias: dimensionamiento, análisis de barreras e identificación de oportunidades, 2018; M. BOLIVAR OÑORO/M. A. RAMIRO AVILÉS, "La contratación de seguros no obligatorios por personas con el VIH", 2016, disponible en https:/www.cesida.org/wp-content/uploads/2013/09/ClinicaLegal_MA_RamiroyM_Bolivar_VIHySeguros.pdf.

${ }^{39}$ También en la Unión europea encontramos algunas normas antidiscriminatorias a destacar en el ámbito penal, como la Decisión Marco 2008/913/JAI, de 28 de noviembre de 2008, relativa a la lucha contra determinadas formas y manifestaciones de racismo y xenofobia mediante el Derecho Penal. En materia de asistencia a víctimas de delitos, encontramos la Directiva 2012/29/UE, de 25 de octubre de 2012, por la que se establecen normas mínimas sobre los derechos, el apoyo y la protección de las víctimas de delitos. 
b) Quienes produzcan, elaboren, posean con la finalidad de distribuir, faciliten a terceras personas el acceso, distribuyan, difundan o vendan escritos o cualquier otra clase de material o soportes que por su contenido sean idóneos para fomentar, promover, o incitar directa o indirectamente al odio, hostilidad, discriminación o violencia contra un grupo, una parte del mismo, o contra una persona determinada por razón de su pertenencia a aquél, por motivos racistas, antisemitas u otros referentes a la ideología, religión o creencias, situación familiar, la pertenencia de sus miembros a una etnia, raza o nación, su origen nacional, su sexo, orientación o identidad sexual, por razones de género, enfermedad o discapacidad.

c) Públicamente nieguen, trivialicen gravemente o enaltezcan los delitos de genocidio, de lesa humanidad o contra las personas y bienes protegidos en caso de conflicto armado, o enaltezcan a sus autores, cuando se hubieran cometido contra un grupo o una parte del mismo, o contra una persona determinada por razón de su pertenencia al mismo, por motivos racistas, antisemitas u otros referentes a la ideología, religión o creencias, la situación familiar o la pertenencia de sus miembros a una etnia, raza o nación, su origen nacional, su sexo, orientación o identidad sexual, por razones de género, enfermedad o discapacidad, cuando de este modo se promueva o favorezca un clima de violencia, hostilidad, odio o discriminación contra los mismos".

En el supuesto de que, por ejemplo, una inmobiliaria deniegue un contrato de alquiler de una vivienda a una persona extranjera por una mera cuestión de discriminación racial, entendemos que resulta aplicable lo dispuesto en el art. 512 del Código penal, que castiga a los que en el ejercicio de sus actividades profesionales o empresariales denegaren a una persona una prestación a la que tenga derecho por razón de su ideología, religión o creencias, su pertenencia a una etnia, raza o nación, su sexo, orientación sexual, situación familiar, por razones de género, enfermedad o discapacidad, incurriendo en la pena de inhabilitación especial para el ejercicio de profesión, oficio, industria o comercio e inhabilitación especial para profesión u oficio educativos, en el ámbito docente, deportivo y de tiempo libre por un periodo de uno a cuatro años.

Quisiéramos señalar por la enorme preocupación que ello nos produce, que los delitos e incidentes de odio aumentaron en nuestro país un 6,8 \% en 2019 con respecto a 2018, y, en concreto, los motivados por racismo y xenofobia fueron los que más se incrementaron, un 20,9\% con respecto al año anterior, según el Informe de la evolución de los delitos de odio del Ministerio del Interior del año $2019^{40}$.

\section{El alcance de la prohibición de no discriminación contractual}

27. Llegados a este punto, nos preguntamos: si quiero alquilar mi casa sólo a personas que presenten una determinada cualidad personal o social, ¿puedo rechazar la propuesta de una interesada en contratar que no la reúna? La respuesta es claramente negativa si en mi anuncio o cartel de arrendamiento indico "abstenerse" y a continuación señalo algún rasgo como la raza, la orientación sexual, la religión, la nacionalidad o la discapacidad, dado que estoy haciendo una declaración al público y una exclusión generalizada. ¿Y cuando se trata de una negociación individual o aislada entre dos particulares sin oferta al público?

Para algunos autores, resulta evidente que un espacio de autonomía debe existir pues, de lo contrario, la libertad contractual corre el riesgo de acabar completamente asfixiada o aniquilada. Por ello, consideran que el principio de no discriminación opera sólo en las ofertas de bienes y servicios hechas al público.

Siguiendo dicha lógica, podría eludirse la prohibición de discriminar no realizando una oferta al público y utilizando, en cambio, una declaración individualizada, hecho éste que permitiría, si así se considera oportuno y con plena libertad, rechazar la celebración de un contrato o imponer condiciones peores en virtud de un factor de riesgo del otro contratante, esto es, discriminando injustificadamente.

\footnotetext{
${ }^{40}$ Informe de la evolución de los delitos de odio en España 2019 del Ministerio del Interior, disponible en http://www. interior.gob.es/documents/642012/3479677/Informe+sobre+la+evoluci\%C3\%B3n+de+delitos+de+odio+en+Espa $\%$ C3\%B1a \%2C\%20a\%C3\%B1o+2019/344089ef-15e6-4a7b-8925-f2b64c117a0a.
} 
Creemos que ello no puede admitirse, puesto que atenta frontalmente contra los valores esenciales del ordenamiento jurídico y, en definitiva, contra la dignidad de la persona. Los comportamientos discriminatorios tampoco pueden darse en el contexto de contratos que son frutos de una negociación individual.

A nuestro juicio, el error reside en considerar que autonomía privada y prohibición de discriminar son del todo punto incompatibles, de manera que la libertad contractual prevalece en las negociaciones aisladas en tanto que la prohibición de discriminación en las declaraciones al público. Sin embargo, la prohibición de discriminar no niega la libertad de elección de la otra parte contratante, ni siquiera cuando el oferente dirige su declaración al público. El problema de la discriminación contractual no gira en torno a la concreta técnica de negociación, individual o al público. La persona tiene libertad para elegir a la otra parte contratante, siempre y cuando dicha elección no se funde en un factor de riesgo. Así lo contempla expresamente el art. 3.2 de la Directiva 2004/113/CE, si bien circunscribiéndose a la discriminación por razón de género: "La presente Directiva no afectará a la libertad de la persona a la hora de elegir a la otra parte contratante, siempre y cuando dicha elección no se base en el sexo de la persona contratante".

Dicho de otro modo, la prohibición de discriminación también se aplica a los intercambios de bienes y servicios individuales, en los que no puede existir una suerte de absoluta impunidad ante vulneraciones de los principios y valores constitucionales. Piénsese en el propietario de varias viviendas que sin dirigir su oferta de alquiler al público las arrienda aplicando condiciones contractuales más desfavorables para los inquilinos de una determinada creencia religiosa, prohibiendo que el arrendatario conviva en el inmueble con personas de una determinada raza o bien permitiéndole subarrendar excepto a homosexuales.

En definitiva, al margen de la concreta técnica de negociación, ha de atenderse al caso concreto y realizar una cuidadosa ponderación de los intereses en juego. Y aunque ya lo apuntamos, insistimos, la dificultad en las prácticas contractuales discriminatorias reside, fundamentalmente, en el plano probatorio, lo que, estamos convencidos, justifica su escasa judicialización.

28. Al abordar esta problemática, es lógico pensar en los contratos clásicos o celebrados de manera presencial (offline markets), siendo más difícil representarnos una situación discriminatoria en la contratación digital (online markets como Amazon, eBay, Airbnb, etc.). Sin embargo, la discriminación contractual también existe en el mercado online y con visos de que pueda incrementarse dado su frenético ritmo de digitalización expansión a raíz de la acelerada digitalización mundial provocada por el coronavirus, la cual ha llegado para quedarse.

La popular Airbnb (acrónimo de "airbed and breakfast"), fundada en San Francisco en 2008 (por tanto, en plena crisis económica), con más de 150 millones de usuarios en 2019 en más de 190 países y con salida en bolsa prevista para el año 2020 pero retrasada por causa de la pandemia mundial del Covid-1941, es una plataforma online de alquileres vacacionales que conecta a propietarios de alojamientos con viajeros de todo el mundo. La gigante startup del home-sharing entre particulares propicia la concurrencia online de ofertas de servicios de alojamiento (y "otras experiencias" como excursiones y eventos) por parte de propietarios privados de inmuebles ("anfitriones") y de demandantes de los mismos ("huéspedes") ${ }^{42}$. Tras un intercambio de información relativa a la reserva, anfitrión y huésped suscriben el contrato de alquiler vacacional de la casa, castillo, apartamento o habitación, del cual Airbnb no es parte $^{43}$, limitándose a cobrar a sus anfitriones una comisión de entre el $3 \%$ y el $5 \%$ por reserva. Parece que esta modalidad de contratación bajo el anonimato y no presencialidad podría, en principio, garantizar la irrelevancia de las características personales al momento de suscribir el contrato, no pudiéndose producir,

${ }^{41}$ El 16 de noviembre de 2020 la empresa presentó la documentación para salir a bolsa exigida por la Comisión de Mercados y Valores de Estados Unidos (SEC). El extenso informe en el que detalla sus últimos datos financieros, el impacto de la pandemia, así como las oportunidades y amenazas de futuro puede consultarse en https://www.sec.gov/Archives/edgar/ data/1559720/000119312520294801/d81668ds1.htm.

${ }^{42}$ Así se describe en los Términos de Servicio para usuarios europeos de Airbnb (pueden consultarse en https://www.airbnb. es/help/article/2908/t\%C3\%A9rminos-de-servicio).

${ }^{43}$ Según los Términos de Servicio, "Airbnb no es parte en los contratos suscritos directamente entre Anfitriones y Huéspedes ni constituye un agente inmobiliario, asegurador, organizador o minorista de viajes combinados con arreglo a la Directiva (UE) 2015/2302". 
por consiguiente, prácticas discriminatorias. Pues bien, a pesar de las normas antidiscriminatorias y del modo de contratación a través de dicha plataforma virtual, la discriminación contractual digital existe.

Así lo ha demostrado en Estados Unidos una investigación experimental realizada por dos profesores y un estudiante de Doctorado de la Harvard Business School ${ }^{44}$, la cual reveló una discriminación generalizada contra huéspedes afroamericanos en Airbnb: los blancos tenían más facilidades para reservar una propiedad privada en alquiler en la citada plataforma digital.

Conforme a dicho estudio, el problema reside en la información personal (nombres e imágenes de perfil) que es inherente a muchos mercados en línea (online marketplaces) de la llamada "economía colaborativa" y que puede facilitar la discriminación por parte de los propietarios inmobiliarios basada en la raza, el género, la edad u otras características de los vendedores ${ }^{45}$. En el concreto experimento realizado se centraron en la discriminación por razón de raza (la que, con frecuencia, lleva aparejada también la de la situación socioeconómica), contra la que existen en Estados Unidos, desde hace décadas, numerosas normas antidiscriminatorias (la principal, la ya citada Civil Rights Act de 1964).

Para probar la discriminación racial por parte de los anfitriones de Airbnb, los investigadores crearon veinte cuentas falsas de huéspedes, todas idénticas salvo en los nombres utilizados para cada uno de ellos: diez inducían claramente a pensar que se trataba de personas afroamericanas (p. ej. "Latonya Robinson", "Tamika Willians", "Jamal Jones" y "Rasheed Jackson") y diez a que eran blancas (p. ej. "Anne Murphy", "Laurie Ryan", "Greg O’Brien” y "Brent Baker”), mitad hombres y mitad mujeres, todos elegidos en función de la frecuencia de los nombres de los certificados de nacimiento de los bebés nacidos entre 1974 a 1979 en Massachusetts. Se usaron sólo nombres, no fotos.

Usando estas veinte cuentas de huéspedes, los investigadores enviaron unas 6.400 solicitudes de disponibilidad de alojamiento para un fin de semana a anfitriones de Airbnb con propiedades en Baltimore, Dallas, Los Ángeles, St. Louis, and Washington, DC entre el 7 y el 30 de julio de 2015 y esperaron a recibir sus respuestas durante los treinta días siguientes. Descubrieron que las solicitudes de huéspedes con nombres asociados a personas afroamericanas tenían menos probabilidades de ser aceptadas por los anfitriones respecto de las de los que tenían nombres típicos de personas blancas. En la muestra realizada, los huéspedes supuestamente blancos recibieron una respuesta positiva en un $50 \%$ frente al $42 \%$ de las peticiones provenientes de los de identidad afroamericana ${ }^{46}$, discriminación que no variaba en función del precio o ubicación del alojamiento ${ }^{47}$.

El caso de esta empresa líder mundial en alquileres vacacionales puede ser sólo la punta del iceberg, existiendo, muy probablemente, desigualdades contractuales injustificadas y aún por descubrir en el tráfico privado online $e^{48}$.

${ }^{44}$ Se trata del estudio realizado por B. EDELMAN/M. LUCA, "Digital Discrimination: The Case of Airbnb.com”, Working Paper, 2014, 14-054 (puede consultarse en https://www.hbs.edu/faculty/Publication\%20Files/Airbnb_92dd6086-6e46-4eaf-9cea60fe5ba3c596.pdf) у в. EDELMAN/M. LUCA/D. SVIRSKY, "Racial Discrimination in the Sharing Economy: Evidence from a Field Experiment”, American Economic Journal: Applied Economics, 2017, pp. 1-22 (https://doi.org/10.1257/app.20160213).

${ }^{45}$ Ello es posible porque, como señalan B. EDELMAN/M. LUCA/D. SVIRSKY, "Racial Discrimination in the Sharing Economy: Evidence from a Field Experiment”, cit., p. 2, "Airbnb allows hosts to decide whether to accept or reject a guest after seeing his or her name and often a picture - a market design choice that may further enable discrimination".

${ }^{46}$ Así lo indican B. EDELMAn/M. LUCA/D. SVIRSKY, "Racial Discrimination in the Sharing Economy: Evidence from a Field Experiment", cit., p. 2, quienes en su estudio descubrieron otros datos: "combining our experimental results with observational data from Airbnb's site, we investigate whether different types of hosts discriminate more, and whether discrimination is more common at certain types of properties based on price or local demographics. Our results are remarkably persistent. Both African American and white hosts discriminate against African American guests; both male and female hosts discriminate; both male and female African American guests are discriminated against. Effects persist both for hosts that offer an entire property and for hosts who share the property with guests. Discrimination persists among experienced hosts, including those with multiple properties and those with many reviews. Discrimination persists and is of similar magnitude in high- and low-priced units, in diverse and homogeneous neighborhoods".

${ }^{47}$ B. EDELMAN/M. LUCA/D. SVIRSKY, "Racial Discrimination in the Sharing Economy: Evidence from a Field Experiment", cit., p. 10 .

${ }^{48}$ Así lo califica M. CIANCIMINO, "La discriminazione contrattuale: profili rilevanti per la tutela della persona. Note a margine di un recente dibattito dottrinale", Il Diritto di Famiglia e delle Persone, 2018, p. 8. 